\title{
Coaching Stressors in a Division II Historically Black University
}

\author{
Jamie E. Robbins \\ Methodist University \\ Jenelle N. Gilbert \\ California State University, Fresno \\ Alexandra M. Clifton \\ California State University, Fresno
}

\begin{abstract}
Recently, studies have addressed the stressful nature of the coaching profession, identifying a multitude of stressors among coaches for Division I, national, and international programs (Durand-Bush, Collins, \& McNeill, 2012; Frey, 2007; Levy, Nicholls, Marchant, \& Polman, 2009; Olusoga, Butt, Hays, \& Maynard, 2009). The purpose of this study was to further the research by studying coaches at a Historically Black College/University (HBCU) and Division II (DII) athletic program. Participants included seven head and five assistant coaches across seven sports. All coaches were interviewed, based on a preexisting interview guide (Olusoga et al., 2009). Data were content analyzed using previously agreed upon procedures and submitted in NVivo for further examination (Côté, Salmela, Baria, $\&$ Russell, 1993). Three higher order themes termed Interpersonal, Intrapersonal, and Contextual Stressors emerged and were composed of 16 lower order themes. The most commonly cited interpersonal stressors included athletes, expectations of others, and administration. Performance outcome and lack of control were the most common intrapersonal stressors. Finally, schedule, lack of resources, and job security were the most common contextual stressors. These findings emphasize the stressful nature of the job and the need to identify means for minimizing stressors to improve the athletic experience for all involved.
\end{abstract}

Keywords: coaches, stressors, Division II, HBCU

Robbins is with the Dept. of Physical Education and Exercise Science, Methodist University, Fayetteville, NC. Gilbert is with the Dept. of Kinesiology, California State University, Fresno, Fresno, CA. Clifton is with the Dept. of Recreation Administration at California State University, Fresno. Address author correspondence to Jenelle Gilbert at jgilbert@csufresno.edu. 
Pressure in coaching was ever present, almost a state of being.

-Pat Summitt, 8-time National Collegiate Athletic Association (NCAA) Women's Basketball Championships, 7-time NCAA Coach of the Year.

In terms of stress theory, Lazarus and Folkman $(1984,1987)$ proposed that the stress process is a dynamic interaction between a person and environment. This dynamic interaction is influenced by appraisal and coping resources, and influences one's psychological and physiological response. Physiological ramifications of short-term stress include headaches, muscle tension, chest pain, heart palpitations, disturbed sleep, and increased risk of respiratory infections (Blaug, Kenyon, \& Lekhi, 2007). Over the long term stress can break down the body, damaging arteries and organs and increasing one's risk for cardiovascular disease (McEwan, 2009). Psychological responses may begin with difficulties concentrating (Gelsema, Van Der Doef, Maes, Janssen, Akerboom, \& Verhoeven, 2006; Suinn, 2005), eventually leading to poor decision making, apathy, decreased motivation, in addition to anxiety (Jones, Tanigawa, \& Weisse, 2003). Perpetual stress exposure may eventually lead to burnout, which is characterized by emotional exhaustion, depersonalization, and reduced feelings of personal accomplishment (Maslach \& Jackson, 1984).

The possible stress related ramifications are clearly deleterious for those experiencing the stress, but they may also impact others. In a sport setting, coaches' behaviors have been found to directly impact athletes' self-esteem, enjoyment, anxiety levels, and confidence (Smith \& Smoll, 2007; Williams et al., 2003). According to Price and Weiss (2000), coaches higher in emotional exhaustion, one sign of burnout, were viewed by athletes as providing less instruction, structure, and difficulty at practice, in addition to showing less concern for their athletes. This may be the result of coaches adopting an "I don't care" attitude (Price \& Weiss, 2000). They also found that these coaching behaviors yield athletes with higher levels of anxiety and burnout.

Coaches have also been shown to impact their athletes' motivation, selfperception, and development (Coatsworth \& Conroy, 2006, 2009; Hollembeak $\&$ Amorose, 2005). More specifically, Hollembeak and Amorose (2005) found that coaches' behaviors impacted athletes' feelings of autonomy, relatedness, and perceived competence, which all mediated their feelings of intrinsic motivation. Similarly, Coatsworth and Conroy (2009) found that coaches influence athletes' feelings of competence, as well as their initiative and identity reflection. Though these feelings (e.g., competence) originated within a sport venue, they are thought to promote well-being outside of sport as well (Coatsworth, Palen, Sharp, \& FerrerWreder, 2006).

Coaches are influential because they are deemed responsible for more than just teaching the sport. For example, coaches are often asked to fulfill both physical and emotional needs of their athletes (Stirling \& Kerr, 2013), including the roles of caregiver, protector, rule enforcer, and teacher. They are responsible for athletes' socialization because of their ability to shape values and teach life skills related to confidence building, stress management, and respect (Côté \& Hay, 2002; Danish, Fazio, Nellen, \& Owens, 2002; McCallister, Blinde, \& Weiss, 2000; Trottier \& Robitaille, 2014). However, oftentimes coaches' roles are in direct conflict with 
each other as they must satisfy the demands of their administration, the media, alumni, faculty, and the student-athletes themselves (Singer \& Armstrong, 2001). It is posited that all of these duties and responsibilities, which can be contradictory in nature (Singer \& Armstrong, 2001), likely contributed to Coach Summitt experiencing a perpetual state of pressure.

Given the numerous responsibilities and requirements of coaches, together with the gravity of a mistake or misstep, it is not surprising that Olympic, international, and NCAA Division I (DI) coaches have expressed numerous stressors (Durand-Bush, Collins, \& McNeill, 2012; Frey, 2007; Levy, Nicholls, Marchant, \& Polman, 2009; Olusoga, Butt, Hays, \& Maynard, 2009). Sullivan and Nashman (1993) studied coaches whose teams had qualified for the 1992 Olympic Games. The most common stressors were related to their role and the demands of the job, as well as interpersonal and personal demands. Sources of stress mentioned by DI coaches came from others (i.e., the job is contingent on the performance of 18- to 22-year-olds), from themselves (i.e., having high personal expectations), and stress related to recruiting (i.e., time requirements). An even wider range of stressors were mentioned by a group of elite coaches from the UK, who experienced stress resulting from a lack of cohesion within their team or organization, others interfering with their coaching, having to collaborate with outside organizations, and the pressure to "achieve results" (Olusoga et al., 2009, p. 451).

These divergent and overlapping stressors found in the literature demonstrate the complexity of stress in the coaching context. Although some stressors (e.g., pressure from within and external expectations) likely impact most high-level coaches, it seems plausible that the coaching context and individual differences may be more significant than the profession alone in deciphering factors directly impacting experienced stress. Following this thinking, Durand-Bush et al. (2012) hypothesized that women would have more stress than their male counterparts. Interestingly, the female coaches in the study did experience several of the same stressors as male coaches, with additional stress caused by family, friends, school, and other job requirements outside of coaching.

The concept of work-family conflict impacting coaches' attitudes, stress, and decisions was further studied by Dixon and Bruening (2007), who found female DI coaches experience work-family conflict because of individual characteristics, organizational/structural factors, and sociocultural influences. Dixon and Bruening's (2005) multilevel framework of work-family conflict in sport demonstrates the complex interaction of the aforementioned variables on perceptions of conflict and resultant feelings of stress. As such, stress needs to be explored among a more diverse group of coaches in varying contexts in hopes of identifying means for minimizing the stressors, or helping coaches cope with their environment.

Division II (DII) coaches at Historically Black Colleges and Universities (HBCUs) would be a beneficial addition to the literature given scant existing research on this population. As well, it may illuminate whether stress is experienced because of inherent institutional differences between their work environment and that of the national, international, and DI level coaches. DII schools promote balance between academics, athletics, and community service (NCAA, 2012). Although this is admirable, it may be a source of stress for DII coaches as their athletes may have chosen a DII school to ensure a more diverse and balanced college experience, possibly leaving them less time and attention for sport alone. 
Revenue for the NCAA 2010-2011 season brought in nearly 850 million dollars, with $69 \%$ of that going back to DI teams and only $5 \%$ being distributed to DII teams (Lawrence, 2013). Limited funds in DII programs convert to fewer scholarships than their DI counterparts. This leaves coaches with the added challenge of finding alternative funding sources to assist athletes who require more financial aid, and dealing with those athletes whose lack of scholarship funds contributes to feelings of burnout (Judge, Bell, Theodore, Simon, \& Bellar, 2012). The limited resources also impacts the number of support staff an athletic department can hire, which in turn can translate into coaches overseeing not just the athletic development, but also the academic development of their student-athletes (Nite, 2012).

The aforementioned issues, in addition to the reality of academic performance outcomes at HBCUs, may further increase coaching stress. HBCUs were originally created to provide opportunities to blacks who were often refused admission into other colleges (Allen \& Jewell, 2002; Esters \& Strayhorn, 2013). Today the mission of educating black students is still important as HBCUs aim to promote social justice, empower black students, and create strong black leaders (Esters \& Strayhorn, 2013). Presidents of these public land-grant HBCUs describe them as "the people's universities" because of their focus on public service and desire to educate the underserved (Esters \& Strayhorn, 2013). As noted by Dr. George Wright, President of HBCU Prairie View, his institution has a lower APR (academic progress rate), but Prairie View "gives some folks a second chance, and in some cases a first chance to attend college. That mission is important" (Hosick, 2011, p. 2). To achieve these outcomes, HBCUs admit higher numbers of low-income, first-generation, and underprepared student-athletes as compared with other fouryear colleges (Johnson, 2013).

The academic preparation, or lack thereof, may be further exacerbated in the athletic context. More specifically, HBCUs often have smaller budgets as compared with their competitors at larger institutions. Lack of funds means long bus rides, sometimes across state lines, for HBCU student-athletes when traveling to compete (Brandt, 2014). Whether the bus rides are to a competition within the conference or for a guarantee-money game (i.e., a game where a visiting team is guaranteed a specific amount of money from the home team), the end result is the same; the student-athletes are excessively away from the classroom (Hosick, 2011). Some HBCU coaches enforce study hall hours and "quiet time" on the team bus for their student-athletes (Charlton, 2011), but not all do. These circumstances may contribute to eventual graduation rates. NCAA calculates APR based on athlete eligibility, retention, and graduation (Grasgreen, 2013). Eighteen schools were penalized for not meeting these standards for the 2012-2013 academic year; 15 of them were HBCUs (Grasgreen, 2013).

Taken together, it seems clear that coaching is inherently a stressful job. According to Lazarus and Folkman's stress theory (1984, 1987), an imbalance between available resources and environmental demand lead to stress. In an athletic environment, the outcomes of the experienced stress response can be negative for the coaches themselves, but they also could have deleterious effects on athletes. As such, it is imperative to more completely study this issue among coaches working at DII HBCUs. The mission of the schools, students accepted, and requirements of coaches are unique to DII HBCUs, yet no studies have focused on this population. Currently there are 307 DII colleges in the United States, Canada, and Puerto Rico 
(NCAA, 2015) and 107 HBCUs (US Department of Education, 2015). This is a large population, which to this point has been neglected in the stress and coaching literature. Therefore, the purpose of the current study was to investigate stressors in a subsample of DII HBCU coaches.

\section{Methods}

\section{Participants}

The sample comprised coaches (i.e., seven head and five assistant coaches) from the same Southern DII HBCU on the East Coast (see Table 1). The participating coaches had between 2 and 36 years of coaching experience overall, with an average of 2.4 years at the current institution. They represented male and female individual (i.e., cross-country, tennis, and track) and team (i.e., baseball, basketball, football, and volleyball) sports. The coaches identified themselves as black $(N=8)$ and white $(N=4)$, three of whom were female and the remaining nine were male. Two levels of coaches were included (i.e., head and main assistant coaches) as a means of obtaining the most comprehensive portrait of the stressors experienced by coaches employed at a DII HBCU.

\section{Table 1 Participant Demographics}

\begin{tabular}{|c|c|c|c|c|c|c|c|}
\hline $\begin{array}{l}\text { Name } \\
\text { (Pseudonym) }\end{array}$ & Position & Sport & Age & Gender & Race & $\begin{array}{c}\text { College } \\
\text { coaching } \\
\text { experience }\end{array}$ & $\begin{array}{c}\text { Years at } \\
\text { current } \\
\text { job }\end{array}$ \\
\hline Devin & Head & Baseball & 30 & Male & White & 2 & 2 \\
\hline Matthew & Assistant & Baseball & 27 & Male & White & 2 & 2 \\
\hline Joey & Head & Men's Basketball & 46 & Male & Black & 18 & 6 \\
\hline Richard & Assistant & Men's Basketball & 34 & Male & Black & 5 & 3 \\
\hline Connor & Head & $\begin{array}{l}\text { Women's } \\
\text { Basketball }\end{array}$ & 32 & Male & Black & 11 & 2 \\
\hline Beckie & Assistant & $\begin{array}{l}\text { Women's } \\
\text { Basketball }\end{array}$ & 31 & Female & Black & 2 & 2 \\
\hline Tasha & Assistant & $\begin{array}{l}\text { Women's } \\
\text { Basketball }\end{array}$ & 34 & Female & Black & 8 & 2 \\
\hline Crystal & Head & $\begin{array}{l}\text { Men's/Women's } \\
\text { Cross Country } \\
\text { and Track }\end{array}$ & 40 & Female & Black & 7 & 2 \\
\hline Chip & Head & Football & 43 & Male & Black & 12 & 2 \\
\hline Patrick & Assistant & Football & 58 & Male & White & 34 & 2 \\
\hline David & Head & $\begin{array}{l}\text { Men's/Women's } \\
\text { Tennis }\end{array}$ & 31 & Male & White & 2 & 2 \\
\hline Damon & Head & $\begin{array}{l}\text { Women's } \\
\text { Volleyball }\end{array}$ & 49 & Male & Black & 11 & 2 \\
\hline
\end{tabular}




\section{Procedure}

After obtaining institutional consent for the use of human subjects all head coaches and main assistant coaches from one college were invited to participate in the study. Though a convenient sample due to its geographical proximity, the school met the study's criteria for inclusion: (a) DII, (b) HBCU, and (c) coaches were willing to share their experiences of stress working in the DII HBCU context. All coaches contacted agreed to participate with the exception of one head coach and one main assistant coach from the same program who had scheduling conflicts. A mutually convenient interview time was arranged, but in an effort to establish rapport, the first author interacted with each coach before the interview. All interviews were conducted by the first author on campus in the coaches' offices. Coaches were provided with an informed consent form before the interview; once consent was obtained, the interview began. Olusoga et al.'s (2009) semistructured interview guide, which was created based on existing stress literature (e.g., Frey, 2007; Thelwell, Weston, Greenless, \& Hutchings, 2008), was used to enhance consistency in the research of stress in coaching, and to allow for more reliable comparison of the results. The first section of the guide addressed demographic issues and general questions to help the interviewer enhance rapport. Section two asked stress specific questions, including: (a) do you find the job to be stressful, and if so, (b) what makes it stressful? All questions had follow-up probes to gain more detail if coaches were brief or incomplete in their responses. Interviews lasted between 45 and $80 \mathrm{~min}$ and were audiotaped. Verbatim transcription yielded 132 single-spaced transcript pages.

It was believed that the first author's training, experience, and preparation resulted in effective interviews with the participants, which was validated by a member check process. Lincoln and Guba (1985) noted that member checks are the most crucial technique for establishing credibility of a study's results. In this technique, data and the researchers' interpretations are tested with participants to ensure their accuracy. Each coach was provided a copy of their transcribed interviews and asked to make any changes or modifications they deemed relevant. No coaches returned their interviews during this phase. Following data analysis, the researchers created summaries describing each coach, utilizing the emergent themes, and again provided the write-ups to the coaches for feedback. Only three coaches provided changes, which were minor and mostly related to correcting their demographic information. The remaining coaches did not respond or stated the summary was accurate, thus the researchers deemed their analyses to be appropriate representations of the coaches.

Another important consideration for the study related to data saturation. The number of participants selected for a study depends on the nature of the topic and resources available (Gaskell, 2000). In addition, samples should include participants who best represent the research topic (Morse, Barrett, Mayan, Olson, \& Spiers, 2002). Regardless, key questions related to qualitative studies, which use interview methods for data collection are, "How many interviews is enough?" (Culver, Gilbert, \& Sparkes, 2012, p. 269) and "Is there an optimal number?" to achieve saturation (Guest, Bunce, \& Johnson, 2006). Bowen (2008) and Marshall (1996) noted that adequacy of participants is achieved if the research question can be answered and a sufficient depth and breadth of information is acquired. Furthermore, while acknowledging that each study is different, Guest et al. (2006) discovered that when 
analyzing data, the majority of the variance in the resulting codes and themes had already emerged by the 12 th interview. With respect to the current study, the 12 coach interviews were completed before data analysis. Though there were a few unique stressors identified by the coaches (i.e., Interpersonal-parents, Contextual-new program, Contextual-conference), these stressors were reported in early interviews, but not in subsequent interviews with other coaches. Given this situation and the magnitude of the data for the current study, the researchers believe that saturation was achieved with the 12 participants. Thus, the researchers limited the study to the 12 coaches at the participating school and did not invite coaches from other DII HBCUs to be involved.

\section{Data Analysis}

A review of qualitative research studies demonstrates that there are many different, yet acceptable ways to analyze data, as long as dependability of results is achieved (Schwandt, 1997). Two techniques were used in the current study to address the validity tactic of dependability: peer feedback (i.e., peer debriefing and peer review) and an audit trail.

Analysis started with the first and second authors independently reading the interview transcripts several times in the order that the interviews were completed and coding the data. Initial codes were solely descriptive. Peer review and debriefing meetings were then held weekly where emergent findings were discussed. After all of the interview transcripts were processed in this way, the researchers independently identified the meaning units and tagged them with provisional labels, which described the topic of the text segments (Côté, Salmela, Baria, \& Russell, 1993). This process completed the first step in the audit trail.

The next phase involved coding at a more interpretive level. In this phase of the audit trail, the meaning units were independently listed, and then compared and reviewed during weekly peer meetings. Tesch (1990) noted the process of assembling and reviewing data related to one category, or node, is referred to as 'recontextualizing' the data, which yields a set of categories that serve as a preliminary organizing system. This process was inductively driven, with the category names often coming from the participants' own words. The first and second authors then created definitions for the categories and subcategories, which better informed further data analysis.

At each peer meeting, the first and second authors critically reflected on the organizational system and the categories it included. This process was flexible as categories were modified and refined throughout data analysis (Tesch, 1990), as were the definitions. For example, stress $=$ athletes was initially designated as a major theme and defined as, "factors related to athletes that coaches find stressful to deal with." This specific theme was later subsumed under the broader theme termed interpersonal stressors. Analysis and peer debriefing continued with all interview data until the researchers were satisfied that their definitions adequately captured the data within each category or subcategory. The researchers carefully documented their changes to create a thorough and well organized audit trail.

After the final version of the organizational system was complete and all data were entered in NVivo, the third author was given a random sample of meaning units, the list of definitions, and the current organizational framework, to triangulate the 
findings. Results of this interrater reliability test showed $86 \%$ agreement between the first two authors' and third author's analysis; a minimum of $80 \%$ is considered acceptable (Miles \& Huberman, 1994).

\section{Results}

Content analysis yielded three higher order themes termed Interpersonal, Intrapersonal, and Contextual Stressors, which were composed of 16 lower order themes (Figure 1). Within these three themes, only two differences emerged between the head and assistant coaches with respect to lower order themes; ultimate leader was

Raw data themes

Personal decisions

Classroom issues (e.g., failing classes)

Sport-specific decisions (e.g., selfish, not team players)

Lack of communication with coaches

Negative attitudes (e.g., lack of respect, not listening, talking back, ignoring coaches' advice)

Helpless to solve athletes' problems

Athletes unprepared for college life

Fans

Alumni

Students

Faculty

Staff

Community

Athletics program

About personal lives

Interference regarding coaching decisions

Set office schedule

Paperwork issues

Budgetary support

Professional development funds

Incorrect communications regarding program

Assigned tasks not accomplished

Lack of follow-through

Unrecognized contributions

Lack of understanding
Lower-order themes

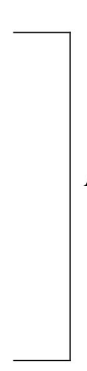

Athletes (6/4)

Expectations from others

$(5 / 2)$

Interpersonal

$(6 / 4)$

Figure 1 - Organizational Framework for Stressor Data (Head Coach/Assistant Coach) 
Desire to win

Hatred of losing

Cannot train/compete for athletes

Cannot fix athletes' lives

Coach "better get it right"
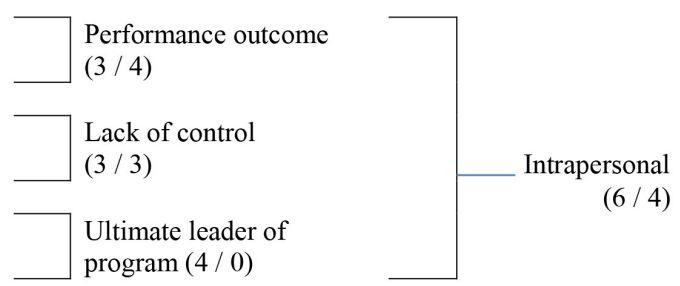

$\square$ Schedule (5/3)

Lack of time

Long hours - time commitment

Difficulties with balance

Money (e.g., impacted travel and recruiting)

Scholarship

Other budget items

Unknown future - contract uncertainty

Difficult on family

Death of parent

Death of athlete

Time needed not worth the salary

Compensation not enough

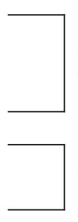

Lack of resources $(5 / 2)$

Job security (4 / 3)

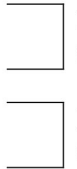

Life events

$(1 / 1)$

Contextual

$(7 / 4)$
Other full-time job

Graduate school

Process of starting a new program

Weakness of teams within the conference Management of conference
Lack of compensation $(1 / 2)$

Outside responsibilities $(1 / 1)$

— New program $(0 / 1)$

Conference

$(1 / 0)$

\section{Figure 1 (continued)}

reported solely by the head coaches, while assistant coaches were the only coaches to discuss compensation as a stressor. There were additional themes identified by only one coach; however, these provided no obvious connection based on coaching status. In addition, there was not complete consensus on any of the stressors by all 12 coaches. Numbers of coaches who expressed each theme are included in the analysis to help identify commonality of stressors; however, all stressors are reported even if they were only mentioned by one coach. Also, coaches were assigned code numbers during data analysis, but pseudonyms are used throughout the manuscript to improve reader comprehension of the findings. 


\section{Interpersonal Stressors}

Interpersonal stressors were defined as stressors relating to or involving relations between people. The most commonly cited interpersonal stressors included athletes, expectations of others, and administration. Six of the seven head coaches and four of the five assistant coaches identified athletes as their greatest stressor. They discussed athletes' personal, classroom, and sport-specific decisions, including failing classes and not communicating this to their coaches. The head tennis coach David explains:

I had a player come to me, "can I get money for summer school?" I'm like, "Well no, there is no money for you to take summer school, you're on your own." Well I come to find out when I got back in August he was academically ineligible because after we had lost in the conference tournament his classes just tanked. And he never relayed that. I had to find out second-hand through a report I got in July, saying he had failed his classes, and I was like why was I not made aware of this? I don't like being blindsided.

Coaches also experienced stress as a result of their athletes' negative attitudes, including a lack of respect, not listening, and talking back. Further, some assistant coaches experienced stress resulting from a perceived inequality in respect. More specifically, Richard stated, "The players may not give you the same respect they give a head coach."

Some coaches were stressed by the sheer variety of attitudes, energy, and effort levels they dealt with on any given day. Crystal, the head women's and men's cross-country and track coach noted that it can be stressful when athletes feel that they know best and ignore the coach's advice.

This semester I have to deal with a couple of (athletes) and it is very, very draining, especially when you know that you are the type of person who knows that that attitude won't bring you anywhere. And it's a tug-a-war [sic] because you definitely know this is right from your heart. This is what's going to help you. You don't understand it's going to help you get to the next level. Whereas, their little minds, some of them think they're grown. Like, "No, she (head coach) doesn't know what she's talking about." So, that's the biggest stressor for me.

The head baseball coach Devin added, "This is one of the things that really ticked me off. This is an example, but when kids would show up late they'd walk from the parking lot to the field on their cell phone."

Other coaches found their athletes to be selfish at times, not team players, and unprepared for college life. Tasha, one of the assistant women's basketball coaches shared her stress regarding "the lack of preparation by the student part of the athlete. They come and they're ready to play basketball, but they're not ready to be a student."

While most coaches experienced stress as a result of negative athlete behaviors and attitudes, Joey, the head men's basketball coach, felt stress because he could not solve all his athletes' problems. More specifically he said: 
It stresses me more what they go through personally. Because I'm like, what can I do, how can I help? And I want to make a difference. I just don't want to fix the problem, what they're dealing with at that moment. I want to have a solution for when you have situations; this is what you do next time. So, it's like I don't want to give you a fish; I want to teach you how to fish.

Expectations of others was a stressor mentioned by five head and two assistant coaches who explained that expectations come from a variety of sources, including fans, alumni, students, faculty, staff and the community. The head basketball coach explained how fans like to share their preferred coaching techniques with him, as he has been told to "cuss them out" or "get into them," when his athletes are not playing up to the fans' expectations. Beckie, an assistant coach for the women's basketball team, was more general in her description of administration's expectations, stating, "I always think our expectations are really high, especially from our administrative staff because of the relationships we've had with them ... the expectations are always high."

The expectations may be even higher if the team or program had been successful in the past. Since David took over as the head tennis coach, the team has done well. He stated, "Within the region we are expected now to every season compete for our conference title as well as compete within the region." Joey echoed this and commented, "We were having a better season than we had last season but because we lost a couple of games at home, the expectations were, be perfect." Coaches also felt pressure if other teams within their athletics program were successful. Damon, the head volleyball coach explained:

There are some programs that don't put pressure on you, they don't care if you win, lose or draw but if you have a program where there is pressure to win then that's added stress. This program happens to be one of them because of the success of other teams. Baseball is winning, football is winning, basketball is winning, softball is winning, tennis is winning. You're the only ones not winning. That's pressure. That's added stress.

Though most of the stress concerning expectations of others was associated with sport performance, coaches also commented that they felt stress regarding their personal lives. Joey, the head men's basketball coach explains:

I go to (name of restaurant/bar) and it's “what are you doing (here)?" I came here to eat and play pool, but I can't do it. I don't do it, but people still judge you by where you are and the company you keep; your walk and your talk. They judge you, everything you do. . . . So there's a lot of pressure. I can't go certain places. I can't do certain things. I have to walk a straight and narrow like a pastor.

Administration, including athletic directors and other administrative personnel, was mentioned as a stressor by four head and three assistant coaches. Coaches noted that administrators often interfere with them and tell them how to do their jobs. Joey stated, "Well I've had my boss say, 'Hey you've got to crack down on your guys. You've got to have more discipline." Some administrators have set 
hours coaches must be in the office during the off-season and disciplined them for not following these demands.

Right now we work the hours we work during the year. I mean, you're talking, no days off, at the latest you'd probably be able to come to work is 10 o'clock during the week. The earliest you'll go home is 7:30, 8:00 and that's probably not including you've got to take film home with you and make recruiting phone calls when you get home. Sunday's not off and they're making us come to work every day now, 8:30-5. ... With all the technology we have, with the smart phone, emails coming to your phone, you can check your voicemail from another phone. With all that (hand gesture), I've gotten five write-ups in the last year. Just got one last week. That's another stressor. (Connor, head women's basketball coach)

In addition to creating what some coaches perceive to be futile rules, administrators also create stress when they do not follow through with required paperwork. Devin explains, "After you submit your paperwork, push it through finance administration, through the executive director to sign off and it sits on desks or it gets messed up somewhere it puts me behind and it starts coming back directly to me."

Stress is also experienced as a result of perceived unequal or inadequate provision of budgetary support and professional development funds. For example, the administration gives fall and winter sports their full budgets, but then expects the spring sports to make cuts and return part of their allocated budget. This creates stress for the spring sport coaches. Tasha, an assistant women's basketball coach explains how she received little support from the administration in terms of a professional development opportunity:

Just recently I attended a conference - they didn't approve to pay for it. If I wanted to go I had to pay for it myself, but it's professional development and then they said, "We'll give you part of it." Then I got back and they said "no I didn't say that." So that's frustrating, you know?

Administrators serve as the voice of the athletics program by posting information on the web site and communicating with the NCAA. When there is a lack of or incorrect information used, this also creates stress for some coaches. The head baseball coach, Devin, discusses how inaccurate data and grammatically incorrect postings contribute to a stressful situation.

Last year when our record was submitted to the NCAA for the selection of what seed you are in the regional they sent a record that was wrong and had us having 6 more losses than we actually did and we were seeded as the lowest seed in the regional because of that. We had two teams who had worse records than us that were seated above us. So here we are playing the number one seed when we probably should have been a 3 or 4 seed playing the other 3 or 4 seed. So it's detrimental to the outcome of your season. The thing is, statistics are not updated on a daily basis. And a lot of that stuff has to do with how outside people perceive your program and when outside people are reading a story published on your website or a quote that's given from you or one of your teammates and it's completely wrong or there are misspelled words or things like that, misinformation, it's embarrassing. 
Unfortunately, the stress experienced by coaches as a result of administration may lead to drastic outcomes. In fact, Devin explained, "I was ready to resign just because all the little things were stressing me out from administration, where it was getting to the point it was just not worth it to continue on."

Additional stressors in the Interpersonal Stressors category included staff dynamics and parents. Head coaches experienced stress as a result of their assistant coaches not getting tasks accomplished. When talking about his assistants Joey noted, "If I delegate the responsibility, I want to know that you're going to get it done. I don't want to have to check behind you with everything that you do." Devin, the head baseball coach, also said:

Another huge stress is when assistant coaches don't follow through with meetings they scheduled. For example, one of my (assistant) coaches sets up sessions with the athletes and then calls me because something comes up and he can't make it. It's stressful.

These feelings are not only one directional, as assistant coaches also felt stress as a result of their interactions with their head coaches. For example, Richard, the men's basketball assistant coach experienced a lot of stress when his contributions were perceived as unimportant to the head coach or when he didn't perform to the head coach's expectation. He stated, "I would say the biggest thing that stresses me out is when my head coach tells me I didn't do a good job of doing a certain task that I was handed."

The final group of people identified by the coaches as increasing their stress is parents. Connor, the head women's basketball coach, explained that an athlete's parents did not understand the team's budget issues or why their daughter could not receive a full scholarship, and having to deal with this situation created stress for him. Taken together, coaches may experience stress as a result of their interactions with a multitude of people on any given day; yet, other people are not coaches' only sources of stress.

\section{Intrapersonal Stressors}

Intrapersonal stressors were defined as stressors that arose within the coaches' minds or self. They were deemed to be the result of their own interpretation of their situation. Performance outcome and lack of control were the most common intrapersonal stressors, with three head and four assistant coaches identifying performance outcome as their greatest stressor. Performance outcome was composed of coaching stressors created by a desire to win and hatred of losing. Beckie, the assistant women's basketball coach stated:

We're disappointed with the season that we had even though we were 18-6. We still felt like we could have pushed just a little bit harder. We could have bounced the ball one more time. We could have jumped a little bit higher. We could have done so many different things to change the outcome.

Due to his unexpected success in the prior season, Damon, the head volleyball coach, perceived that he could and should win the championship in the following year, which would only increase his stress level. 
This year will probably be a lot more stress on me because I expect now to win it because having gotten that far this year, not expecting to, I realize we're a step ahead of where we wanted to be and needed to be and so I don't expect anything less than a championship this (coming) year.

In addition to wanting to win, many coaches like to be in total control of the situation. Six coaches (three head and three assistant coaches) experienced stress termed lack of control. The coaches acknowledged that they cannot train/compete for their athletes, which increases their stress level on the sideline. Chip, the head football coach, noted:

You know we can't play anymore. We can just prepare the players to play and not knowing how they're going to perform and if they're going to perform at a high level and seeing kids make mistakes you know they shouldn't be making that you practiced. That's stressful seeing them making the same mistakes over and over and you can't quite understand why.

Coaches also recognized that they cannot fix other aspects of their athletes' lives. For example, Tasha, an assistant women's basketball coach, said:

It does get difficult also when a kid has a financial problem that they can't do anything about, or a very tough home life - mother's in jail or mother's on drugs or divorce. We had to deal with the death of an athlete this year. Those types of things are out of our control.

Although they recognize that they put the pressure on themselves to win and they truly cannot control every part of their athletes' lives, they still experience the stress effects.

The final intrapersonal stressor was experienced by head coaches only. They explained that being the ultimate leader of the program created stress because at the end of the day, the fault was on them and "they better get it right." Regardless of who makes the mistake (i.e., assistant coach or athlete), it is the responsibility of the head coach. This was explained best by Connor, the head women's basketball coach, who said:

It's kind of like being a king of a country or president of a country, you know, just because you're in control of it, you don't run it the right way, it will turn on you. And I think that's a stressor of making sure you stay on top of yourself. You can't always look and say it's the vice president, it's the secretary, it's this person, it's that person; you're the one who hired all them [sic] people. Look at yourself.

\section{Contextual Stressors}

Contextual stressors are defined as the unchangeable, inherent realities of the coaching profession. Schedule, lack of resources, and job security were the most common contextual stressors. Schedule specific stressors include those related to their schedule itself, lack of time, long hours, and balance difficulties in the lives 
of coaches. This theme was mentioned by eight coaches in total, five head and three assistants. Several coaches explained the difficulties in balancing personal and work life effectively. For example, Tasha said:

You're kind of in a relationship with your job because it's 24/7. We can be in the mall, out to dinner, the movies, if I see a 6 foot player, I'm recruiting now. My personal time is totally done. I'm going to find this kid who looks to be a real baller, so it is 24/7. I've upset my family at times because I've left family functions to go watch a practice.

Coaches explained the long hours and the time commitment of the job, and although these variables seem to be a somewhat accepted reality by these coaches, they were still deemed to be stressful. More specifically, assistant coach Matthew explained,

I forgot we have practice after girls' basketball, so I'm not going to be done 'till like 11, 11:30 at night. So, starting right now for baseball, I have to help with strength and conditioning and then we're going to watch the girls' basketball game as a team and then we have practice after that. So, trying to manage having a girlfriend now is [ended thought], and she lives 30 minutes away from my place.

In addition, David, the head men's and women's tennis coach, stated

If you are going to coach you got to realize the time commitment. And I mean even though I am classified as part-time, it requires full-time plus hours. It's not something you can come in and just halfway do if you want to be successful. And if your athletic department wants you to be successful, you're going to have to put in the time. You have to make sacrifices and, you know, if you're in a relationship whoever you're with got to be on board as well... because if they're not you're fighting a losing battle.

Another commonly cited contextual stressor was lack of resources, defined as money, scholarship, and budgetary issues. Connor went on to explain,

I think the main thing that you encounter at the Division II level is resources. You don't all the time have the resources that you need, right there within an arm's grasp of getting... The two teams that have dominated our conference for the past 10 years, [their] scholarship budget is $\$ 100,000$ more than what we have here, so it's a little hard to compete.

Similarly, Tasha stated, "We don't have the money to, in my opinion, effectively do exactly what we need to do...I can't just get a plane ticket and fly to go watch a kid work out." Taken together, money issues were said to impact their travel, recruiting, and scholarships. As well, coaches know if they do not compete, their job could be at risk. Seven coaches mentioned job security as a stressor. They explained that this can be a stressor for them personally, but also for their current or future family because they never know if they'll have a job once their contract expires. Joey explained this as follows: 
I was head coach at [different university] for 4 years. I was the first year winningest head coach... I lost the championship at the buzzer. My third year I was coach of the year and I lost in the championship game at the buzzer. Then, my $4^{\text {th }}$ year I win the championship. I get fired because I've lost in the championship twice. The expectations were better than that. We should win every game. But, why did I get fired? My coaching style. I was too laid back. My demeanor wasn't the flamboyant, get in your face, scream kind of guy.

Thus, in addition to win-loss record being significant, coaches explained other variables that are used to determine if a coach is hired or fired and why this increases their levels of stress. More specifically, Connor answered in response to being asked if job security scared him, "Yes. I'm currently in the last year of my contract...And it's one of those things to where you never know what the person who has the pen to give you another contract is thinking." Additionally, Matthew said, "It's kind of a family thing too. From year to year, I don't know where my life's going."

Life events, lack of compensation, outside responsibilities, new program and conference were additional contextual stressors for the coaches in this study. Although these themes were only mentioned by one or two coaches, they represent the variety of stressors experienced by these Division II coaches at an HBCU. Life event stressors included the death of a parent and the death of an athlete. Damon explained the stressful situation he experienced during the season when his mother died. He discussed the inner struggle he had over wanting to stay with his brothers and family following the funeral and getting back to his team for an important game. Two coaches had responsibilities outside coaching, including another full-time job and graduate school they deemed stressful. Devin explained, "Most of my stress comes from my Ph.D. and that's my big thing that makes me the most angry (sic), changes my mood the most. It's the feeling of not fulfilling those Ph.D. requirements." One coach mentioned the stress of starting a new program, while another explained that the weakness and management of the athletic conference was his major stressor. More specifically, David said:

For me, it's our conference. I hate the way our conference is run. They have no faith in the coaches, in terms of scheduling or anything like that and our conference is so weak, on the tennis side it really does me no good to play but maybe one or two teams in our conference.

\section{Discussion}

Division II, HBCU coaches experience a wide variety of stressors that fall into three major categories termed: (a) interpersonal, (b) intrapersonal, and (c) contextual. Within the three main categories, coaches specified 16 different types of stressors. These findings support previous research identifying coaching as an inherently stressful profession (Durand-Bush et al., 2012; Frey, 2007; Levy et al., 2009; Olusoga et al., 2009) and confirm the dynamic interaction of person and environment in the stress response (Lazarus \& Folkman, 1984).

Interpersonal stressors reflect coaches' feelings regarding their interactions with others. Although existing research focuses on the impact of coaches on 
athletes' experiences (Smith \& Smoll, 2007; Smoll \& Smith, 1989; Williams et al., 2003), the current results demonstrate the possible negative impact of athletes on coaches' experiences. In fact, the most common stressor mentioned by 10 of the 12 coaches was athletes.

Athlete behaviors and the athletes themselves are stressors for many college coaches. For example, DI coaches reported that their stress results from relying on 18- to 22-year-olds "making the right decisions and doing the right things" (Frey, 2007, p. 46). Though all collegiate athletes are considered student-athletes, DII HBCUs generally accept a population of student-athletes who want a balance between academics, athletics, and community service, as well as many underprepared, first-generation students (Hosick, 2011; Johnson, 2013). These multiple foci and the lack of preparation for the college experience may be magnified at the DII HBCU level, which in turn can exacerbate coach stress. Regardless, DII coaches are ultimately responsible for the final selection of their athletes. As such, spending more time with athletes during the recruiting process, but especially upon their initial arrival on campus may provide a greater opportunity for coaches to discuss expectations regarding performance and behaviors, and offer athletes social support as they navigate the transition into their new school. Social support has been identified as instrumental to the success of black collegiate athletes (Carter-Francique, Hart, \& Steward, 2013) who predominate at many DII HBCUs. HBCU football and basketball student-athletes identified that social support through the development of "positive and meaningful relationships with their professors, classmates, staff, and others affiliated with the university" helped them to experience success (Cooper \& Hawkins, 2012, p. 180). Further, some coaches may want to use behavior contracts that outline program requirements and expectations, while clearly delineating unacceptable behaviors. The use of contracts, distinctly outlining coach expectations, and offering social support may help modify athlete behaviors, thus alleviating some of the situations that enhance coaches' stress response.

Coaches also experience interpersonal stress as a result of others' expectations. At times, the expectations of administrators, fans, students, faculty, parents, and community members may result in contradictory roles for coaches (Singer \& Armstrong, 2001), and can exacerbate their stress. Olusoga et al. (2009) found that elite level coaches in the UK experienced the same stressors including, (a) parents not understanding and interfering, (b) outside influences wanting their say, (c) lack of efficiency in the organization, and (d) battle with facility management to name a few. Because of the numerous people involved in any sport, there will always be the challenge of working together effectively and efficiently. It is common to discuss teamwork and team cohesion with specific teams, but this concept may need to be extended to athletic departments and sports organizations as a whole. Because all parties play a role in the outcome of the team, it is imperative that each group knows what the other is doing, what is required of them to help the team succeed, and how certain behaviors negatively influence the results.

To this point, the results have highlighted external stressors on a coach, but it is important to recognize that these individuals do not just wait for others to impact their stress level; they too create their own stress. These are people who personally hate losing, want to control the movements and decisions of their athletes, and feel they are fully responsible for all decisions and outcomes made by team members and staff. This finding is consistent with Dixon and Bruening (2007) who found 
that female DI coaches experience stress because of their personality and desire to succeed at home and work. This drive and determination likely attracts many to sport and the coaching profession. Although personality may be unchangeable, learning coping skills and setting performance goals that focus on accomplishments other than winning may minimize the negative effects such as stress when winning is not the final outcome.

The third category of stressors, termed contextual, include stressors that coaches experience due to the unchangeable issues inherent in their context. The DII HBCU coaches reported schedule organization, balance issues, job security, and lack of resources. Job security is an especially important stressor when considering the difficulties African American coaches experience when seeking employment at the collegiate level (Bopp \& Sagas, 2012; Singer, Harrison, \& Bukstein, 2010). With respect to a lack of resources, HBCUs encounter significant challenges (Hosick, 2011; Johnson, 2013). DII HBCU coaches may feel isolated if they believe these stressors are limited to their context; therefore, it would benefit them to know that coaches at other levels of competition have expressed similar stressors.

Olusoga et al. (2009) found budgetary and balance issues among elite coaches. Frey (2007) found the schedule, especially related to the long process of recruiting to be a stressor among DI coaches. And Dixon and Bruening (2007) found DI coaches experienced stress as a result of balance issues between work and home. Interestingly, they only studied females, but this concern was mentioned by both males and females in the current study. In 1999 Kelley, Eklund, and Ritter-Taylor found that tennis coaches in the DI, DII, DIII, and NAIA levels had high levels of stress; however, they explained that the type of sport and treatment of DII, DIII, and NAIA as a single group may have influenced the results. Ultimately, the current study helped to confirm Kelley et al.'s (1999) findings, while showing that sport coached may not be the primary antecedent to experienced stress.

Taken together the findings confirm that coaching is undeniably a stressful profession as it sets numerous demands on an individual who is then judged primarily by a win/loss record (Fletcher \& Scott, 2010). However, the context being DI versus DII, or HBCU versus PWI (predominantly white institution) may be less relevant than the coaching context overall. After reviewing existing literature, Fletcher and Scott (2010) speculated that coaches of higher levels would experience more stressors than those at lower levels; however, the current study revealed a vast number of stressors experienced by DII coaches, and results mirrored those found among coaches in a variety of settings. These findings are significant because of the impact stress has on both physical and mental processes of individuals, which can negatively influence health, productivity, and quality of work over time (DeLongis, Coyne, Dakof, Folkman, \& Lazarus, 1982; Kanner, Coyne, Schaefer, \& Lazarus, 1981). Burnout occurring in coaches is a real possibility (Kelley \& Baghurst, 2009; Kelley, Eklund, \& Ritter-Taylor, 1999), and a consequence that should not be ignored.

According to their web site, the goal of the athletic department under study is, "graduating student-athletes and winning championships," with no mention of coaches. Student-athletes are clearly the focus, but it would be difficult to achieve those goals with a group of stressed coaches. Regardless of the school and goals, 
success is unlikely without satisfied coaches who want to stay, work to achieve success, and promote actions that lead to success among their athletes. Therefore, it seems obvious that coaching stressors must be addressed early, among both coaches and athletic departments.

\section{Limitations and Future Studies}

The current study addressed one Southern DII HBCU on the East Coast. These findings provide insights into general and individual stressors experienced by this group of coaches, but external validity is lacking. Therefore, results cannot be generalized to all DII or HBCU coaches. Further studies are necessary to confirm or reject the findings with coaches from similar contexts.

If these stressors are pervasive among various coaches and in different athletic departments, programs could be created to ease the stressors when possible, or help coaches cope with the realities if change is not possible. For example, more training could be provided to administrative staff to ensure paperwork and recruiting related issues are handled effectively and in a timely manner. More complete programs could be created for athletes starting each academic year, highlighting specific issues they would likely address during that year to ease the responsibility from the coaches. As well, sport psychology consultants could be hired to work with coaches and athletes throughout the seasons to teach psychological skills and address topics such as goal setting, coping, relaxation, and focus.

There are few if any concrete approaches to addressing this issue. Although anecdotal information may be gleaned from sport psychology consultants who work with coaches, no clear empirical evidence exists regarding approaches to minimizing the stress experiences for coaches. Future studies should address what is available to coaches, what they are using or would be willing to use, in addition to actual interventions aimed at primary, secondary, and tertiary preventions.

\section{Conclusion}

In summary, the current study exposed experienced stressors of coaches employed at a DII HBCU. Numerous stressors were revealed among this group of coaches, and the noticeable similarities between these coaches and those already studied is significant. Although the results cannot be generalized to all DII HBCU coaches, they do help to confirm the stressful nature of coaching as a profession, and emphasize the need for further study of this group in particular and stress in coaches overall.

Coaches' mistakes are highlighted and win/loss records often determine if they retain employment. Rather than increasing the inherent stress of this occupation, researchers and athletic departments should be identifying means for minimizing stressors for coaches to ensure a more positive situation for all involved. When coaches' stressors are identified, and they are supported in the management of this stress, a motivational environment can be created where everyone involved including coaches, student-athletes, administration, and the wider community benefits. 


\section{References}

Allen, W.R., \& Jewell, J.O. (2002). A backward glance forward: Past, present, and future perspectives on historically black colleges and universities. Review of Higher Education, 25, 241-261. doi:10.1353/rhe.2002.0007

Blaug, R., Kenyon, A., \& Lekhi, R. (2007). Stress at work: A report prepared for The Work Foundation's Principal Partners. Retrieved from The Work Foundation website: http:// tinyurl.com/kqcp867.

Bopp, T., \& Sagas, M. (2012). An examination of African American NCAA DI-FBS football coaches: A five-year update. Journal of Intercollegiate Sport, 5, 153-169.

Bowen, G. (2008). Naturalistic inquiry and the saturation concept: A research note. Qualitative Research, 8, 137-142. doi:10.1177/1468794107085301

Brandt, D. (2014, May 30). Troubling times: Money woes, declining talent plague HBCU football. Retrieved from NCAA News website: http://www.ncaa.com/news/football/ article/2014-05-30/troubling-times

Carter-Francique, A., Hart, A., \& Steward, A. (2013). Black college athletes' perceptions of academic success and the role of social support. Journal of Intercollegiate Sport, 6, 231-246.

Charlton, R. (2011). The role of policy, rituals and language in shaping an academically focused culture in HBCU athletics. Journal of Issues in Intercollegiate Athletics, 4 , 120-148.

Coatsworth, J., \& Conroy, D. (2006). The effects of coach training on self-esteem in youth swimmers: Age and gender effects. Psychology of Sport and Exercise, 7, 173-192. doi:10.1016/j.psychsport.2005.08.005

Coatsworth, J., \& Conroy, D. (2009). The effects of autonomy-supportive coaching, need satisfaction, and self-perceptions on initiative and identity in youth swimmers. Developmental Psychology, 45, 320-328. PubMed doi:10.1037/a0014027

Coatsworth, J., Palen, L., Sharp, E., \& Ferrer-Wreder, L. (2006). Self-defining activities, expressive identity and adolescent wellness. Applied Developmental Science, 10, 157-170. doi:10.1207/s1532480xads1003_5

Cooper, J.N., \& Hawkins, B. (2012). A place of opportunity: Black male student athletes' experiences at a historically black university. Journal of Intercollegiate Sport, 5, $170-188$.

Côté, J., \& Hay, J. (2002). Children's involvement in sport: A developmental analysis. In J.M. Silva \& D. Stevens (Eds.), Psychological foundations of sport (pp. 484-502). Boston, MA: Allyn and Bacon.

Côté, J., Salmela, J.H., Baria, A., \& Russell, S. (1993). Organizing and interpreting unstructured qualitative data. The Sport Psychologist, 7, 127-137.

Culver, D. M., Gilbert, W., \& Sparkes, A. (2012). Qualitative research in sport psychology journals: The next decade 2000-2009 and beyond. The Sport Psychologist, 26, 261-281.

Danish, S.J., Fazio, R.J., Nellen, V.C., \& Owens, S.S. (2002). Teaching life skills through sport: Community-based programs to enhance adolescent development. In V.R. Brewer (Ed.), Exploring sport \& exercise psychology (2nd ed., pp. 269-288). Washington, DC: American Psychological Association. doi:10.1037/10465-013

DeLongis, A., Coyne, J.C., Dakof, G., Folkman, S., \& Lazarus, R.S. (1982). The relationship of hassles, uplifts, and major life events to health status. Health Psychology, 1, 119-136. doi:10.1037/0278-6133.1.2.119

Dixon, M., \& Bruening, J. (2005). Perspectives on work-family conflict: A review and integrative approach. Sport Management Review, 8, 227-254. doi:10.1016/S14413523(05)70040-1

Dixon, M., \& Bruening, J. (2007). Work-family conflict in coaching I: A top down perspective. Journal of Sport Management, 21, 377-406. 
Durand-Bush, N., Collins, J., \& McNeill, K. (2012). Women coaches' experiences of stress and self-regulation: A multiple case study. International Journal of Coaching Science, 6, 21-43.

Esters, L. L., \& Strayhorn, T. L. (2013). Demystifying the contributions of public landgrant Historically Black Colleges and Universities. Voices of HBCU Presidents. Negro Educational Review, 64, 119-134.

Fletcher, D., \& Scott, M. (2010). Psychological stress in sports coaches: A review of concepts, research and practice. Journal of Sports Sciences, 28, 127-137. PubMed doi:10.1080/02640410903406208

Frey, M. (2007). College coaches' experiences with stress- "Problem solvers" have problems, too. The Sport Psychologist, 21, 38-57.

Gaskell, G. (2000). Individual and group interviewing. In M. Bauer \& G. Gaskell (Eds.), Qualitative researching with text, image and sound (pp. 38-56). London: Sage.

Gelsema, T., Van Der Doef, M., Maes, S., Janssen, M., Akerboom, S., \& Verhoeven, C. (2006). A longitudinal study of job stress in the nursing profession: Causes and consequences. Journal of Nursing Management, 14, 289-299. PubMed doi:10.1111/j.13652934.2006.00635.x

Grasgreen, A. (2013, June 17). Uphill battle for HBCU athletes. Retrieved from Inside Higher Ed website: http://www.insidehighered.com.

Guest, G., Bunce, A., \& Johnson, L. (2006). How many interviews are enough? An experiment with data saturation and variability. Field Methods, 18, 59-82. doi:10.1177/1525822X05279903

Hollembeak, J., \& Amorose, A. (2005). Perceived coaching behaviors and college athletes' intrinsic motivation: A test of self-determination theory. Journal of Applied Sport Psychology, 17, 20-36. doi:10.1080/10413200590907540

Hosick, M.B. (2011, May 24). Resources crux of HBCU challenges: Schools face uphill battle in meeting academic standards. Retrieved from NCAA News website: http:// www.ncaa.com/news/ncaa/article/2011-05-24/resources-crux-hbcu-challenges

Johnson, M.N. (2013). Financial and related issues among historically black colleges and universities. Journal of Intercollegiate Sport, 6, 65-75.

Jones, D., Tanigawa, T., \& Weisse, S. (2003). Stress management and workplace disability in the U.S. Journal of Occupational Health, 45, 1-7. PubMed doi:10.1539/joh.45.1

Judge, L. W., Bell, R. J., Theodore, R., Simon, L., \& Bellar, D. (2012). An exploratory examination of burnout in NCAA Division II athletes. Journal of Intercollegiate Sport, $5,230-240$.

Kanner, A.D., Coyne, J.C., Schaefer, C., \& Lazarus, R.S. (1981). Comparison of two modes of stress measurement: Daily hassles and uplifts versus major life events. Journal of Behavioral Medicine, 4, 1-39. PubMed doi:10.1007/BF00844845

Kelley, B., \& Baghurst, T. (2009). Development of the coaching issues survey (CIS). The Sport Psychologist, 23, 367-387.

Kelley, B., Eklund, R., \& Ritter-Taylor, M. (1999). Stress and burnout among collegiate tennis coaches. Journal of Sport \& Exercise Psychology, 21, 113-130.

Lawrence, H. (2013). The impact of intercollegiate athletics financial inequalities. Journal of Intercollegiate Sport, 6, 25-43.

Lazarus, R., \& Folkman, S. (1984). Stress, appraisal and coping. New York: Springer.

Lazarus, R., \& Folkman, S. (1987). Transactional theory and research on emotions and coping. European Journal of Personality, 1, 141-169. doi:10.1002/per.2410010304

Levy, A., Nicholls, A., Marchant, D., \& Polman, R. (2009). Organisational stressors, coping, and coping effectiveness: A longitudinal study with an elite coach. International Journal of Sports Science \& Coaching, 4, 31-45. doi:10.1260/1747-9541.4.1.31

Lincoln, Y.S., \& Guba, E.G. (1985). Naturalistic inquiry. Newbury Park, CA: Sage.

Marshall, M. (1996). Sampling for qualitative research. Family Practice, 13, 522-525. PubMed doi:10.1093/fampra/13.6.522 
Maslach, C., \& Jackson, S.E. (1984). Burnout in organizational settings. Applied Social Psychology Annual, 5, 133-153.

McCallister, S.G., Blinde, E.M., \& Weiss, W.M. (2000). Teaching values and implementing philosophies: Dilemmas of the youth sport coach. Physical Educator, 57, 35-45.

McEwan, B.S. (2009). The brain is the central organ of stress and adaptation. NeuroImage, 47, 911-913. PubMed doi:10.1016/j.neuroimage.2009.05.071

Miles, M.B., \& Huberman, A.M. (1994). Qualitative data analysis: An expanded sourcebook (2nd ed.). Thousand Oaks, CA: Sage.

Morse, J., Barrett, M., Mayan, M., Olson, K., \& Spiers, J. (2002). Verification strategies for establishing reliability and validity in qualitative research. International Institute for Qualitative Methodology, 1, 13-22.

NCAA. (2012). Welcome to Division II. Retrieved from NCAA website: http://www.ncaa.org.

NCAA. (2015). Division II facts and figures. Retrieved from NCAA website: http://www. ncaa.org/division-ii-facts-and-figures?division $=\mathrm{d} 2$

Nite, C. (2012). Challenges for supporting student-athlete development: Perspectives from an NCAA Division II athletic department. Journal of Issues in Intercollegiate Athletics, 5, 1-14.

Olusoga, P., Butt, J., Hays, K., \& Maynard, I. (2009). Stress in elite sports coaching: Identifying stressors. Journal of Applied Sport Psychology, 21, 442-459. doi:10.1080/10413200903222921

Price, M., \& Weiss, M. (2000). Relationships among coach burnout, coach behaviors, and athletes' psychological responses. The Sport Psychologist, 14, 391-409.

Schwandt, T.A. (1997). Qualitative inquiry: A dictionary of terms. Thousand Oaks, CA: Sage.

Singer, J.N., \& Armstrong, K.L. (2001). Black coaches' roles in the holistic development of student-athletes. The Academic Athletic Journal, 15, 114-130.

Singer, J.N., Harrison, C.K., \& Bukstein, S.J. (2010). A critical race analysis of the hiring process for head coaches in NCAA college football. Journal of Intercollegiate Sport, 3, 270-296.

Smith, R., \& Smoll, F. (2007). Social cognitive approach to coaching behavior. In S. Jowett \& D. Lavallee (Eds.), Social psychology in sport (pp. 75-90). Champaign, IL: Human Kinetics.

Smoll, F., \& Smith, R. (1989). Leadership behaviors in sport: A theoretical model and research paradigm. Journal of Applied Social Psychology, 19, 1522-1551. doi:10.1111/j.1559-1816.1989.tb01462.x

Stirling, A., \& Kerr, G. (2013). The perceived effects of elite athletes' experiences of emotional abuse in the coach-athlete relationship. International Journal of Sport and Exercise Psychology, 11, 87-100. doi:10.1080/1612197X.2013.752173

Suinn, R. (2005). Behavioral interventions for stress management in sports. International Journal of Stress Management, 14, 343-362. doi:10.1037/1072-5245.12.4.343

Sullivan, P., \& Nashman, H. (1993). The 1992 United States Olympic team sport coaches: Satisfaction and concern. Applied Research in Coaching and Athletics Annual, March, 1-4.

Tesch, R. (1990). Qualitative research analysis types and software tools. New York: Falmer.

Thelwell, R.C., Weston, N.J.V., Greenless, I.A., \& Hutchings, N. (2008). Stressors in elite sport: A coach perspective. Journal of Sports Sciences, 26, 905-918. PubMed doi:10.1080/02640410801885933

Trottier, C. \& Robitaille, S. (2014). Fostering life skills development in high school and community sport: A comparative analysis of the coach's role. The Sport Psychologist, 28, 10-21. doi:10:1123/tsp.2012-0094. 
US Department of Education. (2015). White House initiative on Historically Black Colleges and Universities. Retrieved from US Department of Education website: http:// www.ed.gov/edblogs/whhbcu/one-hundred-and-five-historically-black-colleges-anduniversities/

Williams, J., Jerome, G., Kenow, L., Rogers, T., Sartain, T., \& Darland, G. (2003). Factor structure of the coaching behavior questionnaire and its relationship to athlete variables. The Sport Psychologist, 17, 16-34. 